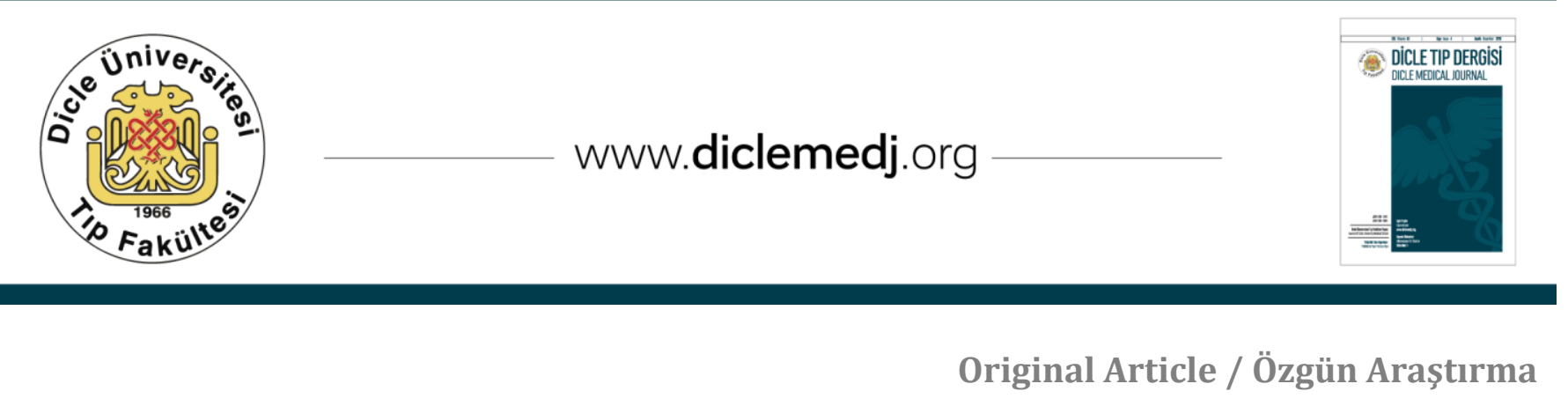

\title{
Breast Cancer Stem Cells and Iron Dependency
}

\author{
Ufuk Ozer ${ }^{1,2}$ \\ 1 Department of Molecular Biology and Genetics, Dicle University, Diyarbakır, Turkey, ORCID: 0000-0002-8362-0592 \\ 2 Center for Colon Cancer Research, University of South Carolina, Columbia, South Carolina, USA
}

Received: 26.01.2018; Revised: 17.04.2018; Accepted: 26.04.2018

\begin{abstract}
Objectives: Among woman, breast cancer is the most prevalent cancer worldwide. It is composed of various cell types that are classified into different subtypes such as triple negative breast cancer (TNBC), triple positive breast cancer (TPBC). TNBCs and TPBCs represent distinct genetic background, thereby leading to therapeutic diversity in breast cancer. It is critical to know their tumorigenic properties to overcome the diversity.

Methods: TPBC cell lines; BT474, HCC1954 and TNBC cell lines; MDA-MB-435, Hs578T, MDA-MB-231 were used to measure intracellular iron levels via a fluorescent probe, calcein-AM, utilizing flow cytometry. Breast cancer stem cells (BCSCs) are detected by surface expression of CD44+/CD24- markers in the lines.

Results: Here, it has shown that TNBCs have higher basal levels of iron and population of BCSCs than TPBCs. Iron addition provides enrichment of BCSCs in TPBCs.
\end{abstract}

Conclusion: Iron is an important element for maintenance of BCSCs.

Keywords: Breast cancer stem cells, iron, TNBC, TPBC

DOI: 10.5798/dicletip.419307

Yazışma Adresi / Correspondence: Ufuk Ozer, Department of Molecular Biology and Genetics, Dicle University, Diyarbakır, Turkey e-mail: ufuk.ozer@dicle.edu.tr 


\section{Meme Kanseri Kök Hücreleri ve Demir Bağımlılı̆̆ı}

Öz

Giriș: Meme kanseri dünya çapında kadınlarda görülen en yaygın kanserdir. Üçlü negatif ve meme kanseri (TNBC) ve üçlü pozitif meme kanseri (TPBC) gibi farklı alt tiplerde kategorilere ayrılan heterojen bir hastalıktır. TNBC'ler ve TPBC'ler farklı genetik altyapıları gösterirler ve bu meme kanserinde terapötik çeşitliliğe yol açar. Bu çeşitliliğin üstesinden gelmek için hücrelerin tümörijenik özelliklerini bilmek çok önemlidir.

Yöntemler: Flowsitometriden faydalanılarak floresan bir prob olan calcein-AM yardımıyla hücreiçi demir seviyelerini ölçmek için TPBC hücre hatları BT474, HCC1954 ve TNBC hücre hatları MDA-MB-435, MDA-MB-231, Hs578T

kullanıldı. Meme kanseri kök hücreleri (BCSCs) hücre hatlarında CD44+/CD24- 'ün yüzey ekspresyonu ile tanımlandı. Bulgular: Burada TNBC'lerinTPBC'lerden daha fazla bazal demire ve BCSC'ye sahip olduğu gösterilmiştir. Demir ilavesi TPBC'lerde BCSC populasyonunun artmasını sağlamıştır.

Sonuç: Demir BCSC’lerin canlılığını idame etmesi bakımından önemli bir elementtir.

Anahtar kelimeler: Meme kanseri kök hücreleri, demir, TNBC, TPBC.

\section{INTRODUCTION}

Breast cancer is the first frequent cancer and remains also the second important matter of cancer death in women worldwide ${ }^{1}$. It has heterogeneity and is classified into Luminal A, Luminal B, human epidermal growth factor receptor type 2 (HER2) positive, triple positive breast cancer (TPBC) and triple negative (basal like) breast cancer (TNBC). Based on molecular and biological properties of the cancer, treatment protocol has designed with drugs targeting interested subtypes. Treatment response varies due to lack of targeted therapy or drug resistance ${ }^{2,3}$.

The major problem in the resistance is the existence of cancer stem cells (CSCs), leading to treatment failure ${ }^{4}$. CSCs are a small subpopulation of neoplastic cells and capable of self-renewal, tumor progression and metastasis ${ }^{5}$. They drive a cellular hierarchy due to their differentiation ability which causes tumor cellular heterogeneity ${ }^{6}$. Therefore, a therapeutic approach could be a selective targeting of CSCs to manage tumor proliferation.

Iron is an essential nutrient that plays a role in functions of vital enzymes involved in DNA replication, cell cycle, cellular respiration, etc ${ }^{7-9}$.
Tumor cells need more iron than their normal counterparts to keep up with increased rates of cell growth ${ }^{10}$. Metabolic process and cellular proliferation could be reduced by iron depletion. This can be achieved by treatment of iron chelators like and di-2-pyridylketone 4, 4dimethyl-3-thiosemicarbazone (Dp44mT), deferasirox, desferrioxamine (DFO) that are used in clinical applications for sequestering iron ${ }^{11-13}$. These compounds have been used as chemotherapeutic drugs for inhibition of cancer cell growth and of maintenance of $\mathrm{CSCs}^{14}$.

Although several studies have done to investigate impacts of iron depletion on breast CSCs (BCSCs), little is known about iron dependency of BCSCs ${ }^{9,15,16}$. In the current study, intracellular iron levels of breast cancer cell lines; MDA-MB-435, MDA-MB-231, Hs578T, BT474, HCC1954, were measured via a fluorescent probe, calcein-AM, utilizing flow cytometry. BCSCs are identified by surface expression of CD44+/CD24- markers in the lines. Effect of iron addition on the population of BCSCs in BT474 and HCC1954 cells was also determined by flow cytometry. 


\section{METHODS}

\section{Cell Culture}

MDA-MB-435, Hs578T, MDA-MB-231, BT474 and HCC1954 cell lines were supplied from the American Type Culture Collection (ATCC, Manassas, VA, USA). Dulbecco's modified Eagle's medium (DMEM), added to $10 \%$ (v/v) fetal bovine serum (FBS; Thermo Fisher Scientific) and $1 \%$ penicillin/streptomycin solution (Invitrogen, Gaithersburg, MD, USA), was used to culture MDA-MB-435, Hs578T and MDA-MB-231 cells. BT474 and HCC1954 cells were cultured in RPMI with 10\% FBS and 1\% penicillin/streptomycin solution. All cell lines were cultured in 5\% CO2 humidification and in $10 \mathrm{~cm} 2$ dishes (New York, USA) at $37^{\circ} \mathrm{C}$. When grown $75-85 \%$ of the dish, cells were replated after digesting them with trypsin (trypsinethylenediaminetetraacetic acid (EDTA), Invitrogen) for each 4 days.

Flow Cytometry for BCSCs

BCSCs were identified by utilizing expression of surface markers (CD44, CD24). Analysis was done with antibodies- anti-CD44-FITC and anti-CD24-PE (BD Biosciences, Franklin Lakes, NJ, USA). Cells were suspended in the buffer (PBS including $0.1 \%$ FBS), set to $1 \times 106$ cells per tube, following treatment of trypsin. For CD44/CD24 assay, antibodies were supplemented to the suspension according to the manufacturer recommendations. Incubation was done without light on ice for 30 min. Iron was exogenously added to the medium as previously done ${ }^{15}$. BD Accuri C6 (Becton Dickinson, San Josè, CA, USA) device was used to run samples and analysis was done with the manufacturers' software. CD44+/CD24- cells on histograms reflects BCSC population.

\section{Flow Cytometry for Iron Detection}

Cells were harvested in trypsin treatment and washed twice with PBS. Staining was applied in serum-free medium including $0.5 \mu$ Mcalcein-
AM (C-AM, Sigma, St. Louis, MO, USA) and cells were incubated for $30 \mathrm{~min}$ in dark at $37^{\circ} \mathrm{C}$. They were washed and suspended in the buffer. Samples were run with BD Accuri C6. For each sample, mean fluorescence was measured and analysis was done using BD's program. Intracellular iron levels were inversely correlated with calcein-AM fluorescence shown in the form of mean fluorescence. The lowest fluorescence, meaning highest iron level, was set as 1 and fold-change was calculated in other cell lines.

\section{Statistical Analysis}

Results are shown as the mean \pm SEM. Statistical significance was considered on $\mathrm{p}$ values $(\leq 0.05)$ calculated by a paired two-sided Student's t test.

\section{RESULTS}

\section{Basal Iron Levels of Breast Cancer Cell Lines}

In order to determine basal iron levels in these cell lines, intracellular iron levels were measured comparatively. MDA-MB-435 cells have the highest iron levels compared to other cells. TNBC cells have higher basal iron levels than TPBC cells (Figure 1).

\section{Comparison of BCSCs Populations}

To determine population of BCSCs in breast cancer cell lines, cells were grown for 5 days and expression of CD44+/CD24- markers were detected. TNBC cell lines represented very high levels, more than 90\%, of BCSC expression, however; it was quite low, less than $2 \%$, in TPBCs compared to TNBCs (Figure 2).

\section{Enrichment of BCSCs via Iron Addition}

TPBC cell lines, BT474 and HCC1954, were treated with $20 \mu \mathrm{M} \mathrm{FeCl} 3$ for 5 days to examine iron-mediated alteration in population of BCSCs. In both cell lines, iron supplement increased BCSC population more than 2-fold (Figure 3). 


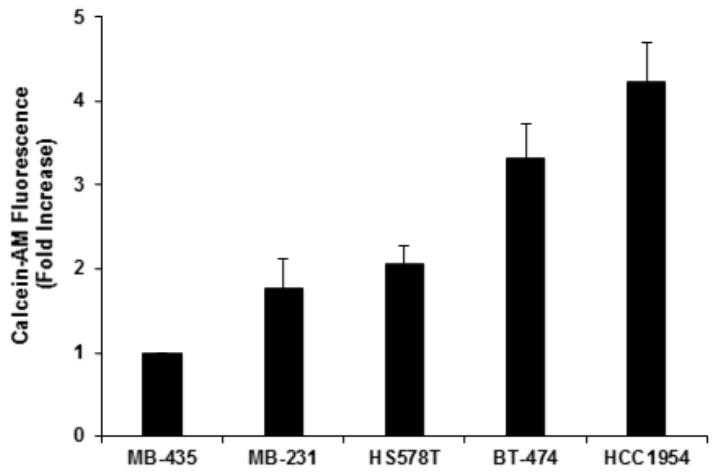

Figure 1. Detection of iron levels in breast cancer cell lines. Cell lines were cultured in appropriate conditions and iron levels were measured by C-AM staining utilizing flow cytometry assay. Bars represent fold increase of the mean fluorescence \pm SEM from 3 experiments.

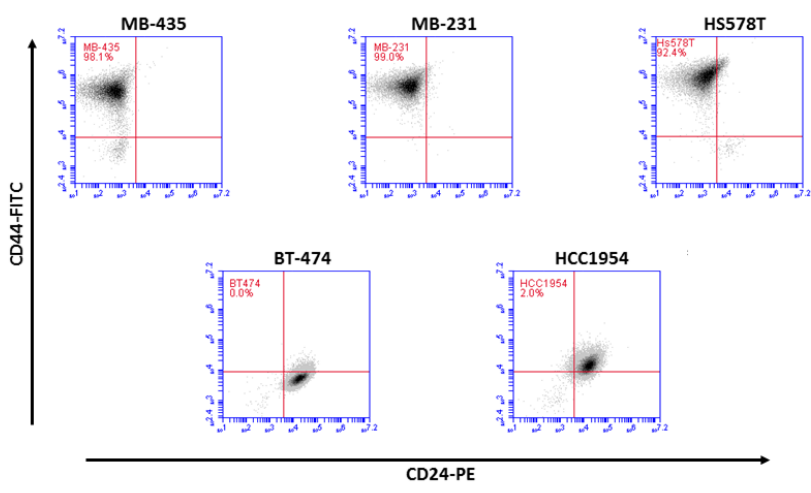

Figure 2. Measurement of CSCs in breast cancer cell lines. Cells were grown in appropriate conditions for 5 days. CD44-FITC and CD24-PE antibodies were used for staining than then flow cytometry assay was done. Results indicate 3 separate experiments.

\section{DISCUSSION}

Breast cancer heterogeneity is very high and the modelling which comprises a panel of genetically and epigenetically distinct diseases with different phenotypical associations has been widely performed utilizing breast cancer cell lines ${ }^{17-20}$. MDA-MB-435, MDA-MB-231 and Hs578T cell lines are known as TNBC cells; estrogen receptor (ER)- progesterone receptor (PR)- HER2- while BT474 and HCC1954 are TPBC cells; ER+PR+HER2+20. As seen in Figure 1 , TNBC cells have higher basal iron levels than TPBC cells and MDA-MB-435 cells have the highest levels. TNBC cells grow fortissimo and are disposed to be more aggressive than other types of breast cancer such as $\mathrm{TPBC}^{21}$. To compensate for aggressive proliferation requirements, they need respectively elevated levels of intracellular iron. Findings are consistent with this phenomenon.

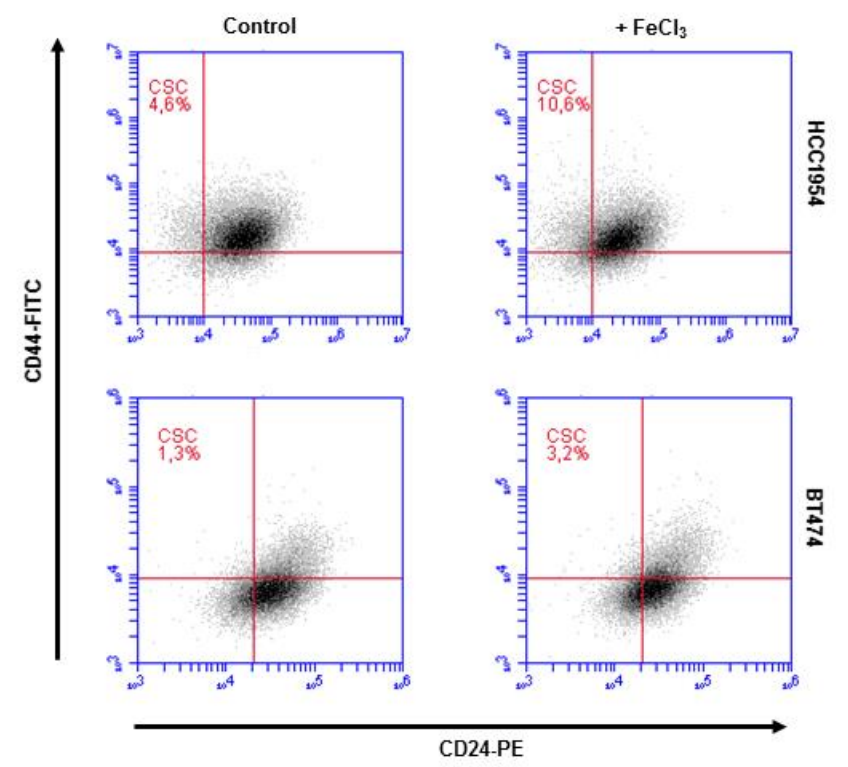

Figure 3. Enrichment of BCSCs in TPBC lines. BT474 and HCC1954 cells were grown in $\pm 20 \mu \mathrm{M} \mathrm{FeCl} 3$ for 5 days. Flow cytometry assay was performed. Results represent 3 separate experiments.

CSCs are subpopulation of tumor cells that grows slowly and have the ability to promote tumorigenesis and metastasis ${ }^{5,22,23}$. CSC phenotype may be characterized by markers of iron-containing proteins. In a recent study, Chekhun et al. found that breast cancer cells exhibiting high degree of malignancy, labeled by the expression of CSC, show the greatest difference in the expression of main proteins of iron metabolism including transferrin, ferritin, ferroportin, hepcidin ${ }^{24}$. Hamai et al. showed that sequestered lysosomal iron by salimomycin and iromycin elevated irondepletion response resulting in iron-induced lysosomal generation of reactive oxygen species (ROS) followed by the death of $\mathrm{CSCs}^{25}$. Conventional cancer therapies aim at 
proliferating neoplastic cells and fail to kill $\mathrm{CSCs}^{26}$. Therefore, brightening what CSCs need to maintain their population provides new goals to improve the therapy efficacy. In present study, populations of BCSCs were determined in the cell lines and they were much higher in TNBC cell lines than those of TPBCs as seen in Figure 2. These results were correlated to the iron content of the cell lines. The more a cell line represents intracellular iron and maintenance of BCSCs, the more chance it has to proliferate aggressively.

There are several studies that have purposed to identify drugs targeting CSCs specifically. Marx et al. found compounds that are able to silence selectively ErbB2 transcription in HER2positive breast cancer cell lines ${ }^{27}$. In another study, Sun et al. identified potential inhibitors of survivin, a tumor antigen related to CSCs [28]. CD44+/CD24- subpopulation of BCSCs was significantly inhibited by salinomycin in a study done by Gupta et al. ${ }^{29}$. It was found that Dasatinib particularly inhibited growth of epithelial-mesenchymal transition (EMT)-stem cell-like cells in $\mathrm{TNBCs}^{30}$. In a recent study, researchers reported that benztropinemesylate inhibited population of BCSCs in vitro and in vivo $^{31}$. These studies have shown selective targeting of CSCs to present promise for novel compounds of cancer therapeutics.

Cancer cells require iron for a number of functions involving proliferation, migration, invasion and metastasis ${ }^{32-34}$.Iron depletion by iron chelators-DFO, deferasirox inhibits the expression of stemness markers on CSCs, indicating significance of iron on the maintenance of stemness ${ }^{15,35}$. In a recent study, researchers have shown that iron chelators repress proliferation of mouse induced pluripotent stem cells growing in Lewis lung carcinoma conditioned medium (miPS-LLCcm) and the expression of stemness markers-Nanog, SOX2, c-Myc, Oct3/7, Klf435. It appears that iron is critical for the proliferation and survival of CSCs. In another recent study,
Raggi et al. reported that DFO diminishes 3D stem-like tumorspheres forming efficiency, the expression of CSC markers and stem-like genes $^{36}$.

Beside these findings, determining cellular requirements of CSCs may provide new targets for the therapy. In current study, it has been shown that there is a link between cellular iron levels and CD44+/CD24- subpopulation of BCSCs in the lines. Basal iron levels in TPBCs are enough to supply iron necessity for cell proliferation, however; they are not growing aggressively like TNBCs. Additionally, they are not generating tumor quickly and highly invasive compared to $\mathrm{TNBCs}^{20}$. This is why TNBCs demonstrate very high levels of BCSCs. It is obvious that tumorigenesis may be enhanced by the supplement of vital nutrients like iron or by presence of high levels of CSCs. Targeting essential genes regulating iron homeostasis or controlling the maintenance of CSCs might be a significant approach to prevent breast cancer.

Acknowledgments - I am thankful to Dr. Hexin Chen for guidance and support by his grant from National Institute of Health, USA (CA178386).

Declaration of Conflicting Interests: The authors declare that they have no conflict of interest.

Financial Disclosure: No financial support was received.

\section{REFERENCES}

1. Ghoncheh M, Pournamdar Z, Salehiniya H. Incidence and mortality and epidemiology of breast cancer in the world. Asian Pac J Cancer Prev. 2016;17:43-6.

2. Shah D, Osipo C. Cancer stem cells and HER2 positive breast cancer: the story so far. Genes and Diseases. 2016;3:114-23.

3. Iancu G, Vasile D, Iancu RC, DaviToiu DV. "Triple positive" breast cancer - a novel category? Rom J MorpholEmbryol. 2017;58:21-6.

4. Colak S, Medema JP. Cancer stem cells - important players in tumor therapy resistance. Febs J. 2014;281:4779-91. 
5. Malanchi I, Santamaria-Martinez A, Susanto E, et al. Interactions between cancer stem cells and their niche govern metastatic colonization. Nature. 2012;481:85-9.

6. Meacham CE, Morrison SJ. Tumour heterogeneity and cancer cell plasticity. Nature. 2013;501:328-37.

7. Lawen A, Lane DJ. Mammalian iron homeostasis in health and disease: uptake, storage, transport, and molecular mechanisms of action. Antioxid Redox Signal. 2013;18:2473-507.

8. Wang J, Pantopoulos K. Regulation of cellular iron metabolism. Biochem J. 2011;434:365-81.

9. Torti SV, Torti FM. Iron and cancer: more ore to be mined. Nat Rev Cancer. 2013;13:342-55.

10. Bystrom LM, Rivella S. Cancer cells with irons in the fire. Free RadicBiol Med. 2015;79:337-42.

11. Merlot AM, Kalinowski DS, Richardson DR. Novel chelators for cancer treatment: where are we now?.Antioxid Redox Signal. 2013;18:973-1006.

12. Dixon SJ, Lemberg KM, Lamprecht $M R$, et al. Ferroptosis: an iron-dependent form of nonapoptotic cell death. Cell. 2012;149:1060-72.

13. Ellis S, Sexton DW, Steverding D. Trypanotoxic activity of thiosemicarbazone iron chelators. ExpParasitol. 2015;150:7-12.

14. Salis O, Bedir A, Kilinc V, Alacam H, Gulten S, Okuyucu A. The anticancer effects of desferrioxamine on human breast adenocarcinoma and hepatocellular carcinoma cells. Cancer Biomark. 2014;14:419-26.

15. Ozer U. The role of iron on breast cancer stem-like cells. Cell Mol Biol. 2016;62:25-30.

16. Ozer U. Copper enriches efficacy of Dp44mT in breast cancer cells. Turk J Biol. 2016;40:1185-91.

17. Riaz M, van Jaarsveld MT, Hollestelle A, et al. miRNA expression profiling of 51 human breast cancer cell lines reveals subtype and driver mutation-specific miRNAs. Breast Cancer Res. 2013;15:R33.

18. Kucukoner M, Kaplan MA, Inal A, et al. Approach to hypersplenism due to splenic metastasis of breast cancer: A case report. Dicle Med J. 2012;39:117-20.

19. Sevimli TS, Sevimli M, Ozcelik N. Protein expression changes in breast cancer and their importance. Dicle Med J 2013;40:161-8.

20. Dai X, Cheng H, Bai Z, Li J. Breast cancer cell line classification and its relevance with breast tumor subtyping. J Cancer. 2017;8:3131-41.

21. Wahba HA, El-Hadaad HA. Current approaches in treatment of triple-negative breast cancer. Cancer Biol Med. 2015;12:106-16.
22. Karnoub AE, Dash AB, Vo AP, et al. Mesenchymal stem cells within tumour stroma promote breast cancer metastasis. Nature. 2007;449:557-63.

23. Nguyen LV, Vanner R, Dirks P, Eaves CJ. Cancer stem cells: an evolving concept. Nat Rev Cancer. 2012;12:133-43.

24. Visvader JE, Lindeman GJ. Cancer stem cells in solid tumours: accumulating evidence and unresolved questions. Nat Rev Cancer. 2008;8:755-68.

25. Chekhun VF, Lukianova NY, Chekhun SV, et al. Association of CD44+CD24-/low with markers of aggressiveness and plasticity of cell lines and tumors of patients with breast cancer. ExpOncol. 2017;39:203-11.

26. Hamai A, Caneque T, Müller S, et al. An iron hand over cancer stem cells. Autophagy. 2017;13:1465-6.

27. Marx C, Berger C, Xu F, et al. Validated highthroughput screening of drug-like small molecules for inhibitors of ErbB2 transcription. Assay Drug Dev Technol. 2006;4:273-84.

28. Sun M, Lou W, Chun JY, et al. Sanguinarine suppresses prostate tumor growth and inhibits survivinexpression. Genes Cancer. 2010;1:283-92.

29. Gupta PB, Onder TT, Jiang G, et al. Identification of selective inhibitors of cancer stem cells by highthroughput screening. Cell. 2009;138:645-59.

30. Finn RS, Dering J, Ginther C, et al. Dasatinib, an orally active small molecule inhibitor of both the src and abl kinases, selectively inhibits growth of basaltype/"triple-negative" breast cancer cell lines growing in vitro. Breast Cancer Res Treat. 2007;105:319-26.

31. Cui J, Hollmen M, Li L, et al. New use of an old drug: inhibition of breast cancer stem cells by benztropinemesylate. Oncotarget. 2017;8:1007-1022.

32. Ohara T, Noma K, Urano S, et al. A novel synergistic effect of iron depletion on antiangiogenic cancer therapy. Int J Cancer. 2013;132:2705-13.

33. Urano $\mathrm{S}$, Ohara $\mathrm{T}$, Noma $\mathrm{K}$, et al. Iron depletion enhances the effect of sorafenib in hepatocarcinoma. Cancer BiolTher. 2016;17:648-56.

34. Nishitani S, Noma K, Ohara T, et al. Iron depletioninduced downregulation of $\mathrm{N}$-cadherin expression inhibits invasive malignant phenotypes in human esophageal cancer. Int J Oncol. 2016;49:1351-9.

35. Ninomiya $\mathrm{T}$, Ohara $\mathrm{T}$, Noma $\mathrm{K}$, et al. Iron depletion is a novel therapeutic strategy to target cancer stem cells. Oncotarget. 2017;8:98405-416.

36. Raggi C, Gammella E, Correnti M, et al. Dysregulation of iron metabolism in cholangiocarcinoma stem-like cells. Sci Rep. 2017;7:1-12. 